Journal of Applied Finance \& Banking, Vol. 10, No. 6, 2020, 225-239

ISSN: 1792-6580 (print version), 1792-6599 (online)

https://doi.org/10.47260/jafb/10611

Scientific Press International Limited

\title{
A Study of Taiwanese Banks' Home Loan Life Insurance Attached to Home Loans
}

\author{
Pih-Shuw Chen', Jia-Jan Lee ${ }^{2}$ and Pei-Fen, $\mathrm{Ou}^{3}$
}

\begin{abstract}
The purpose of this study is to understand the main factors influencing the additional purchase of home loan life insurance at the time of home loan processing with Taiwan's banks. We used Taiwanese banks 417 customers who applied for housing guarantee loans from between 2014-2018. The chi-square test shows that gender and occupation significantly influence the purchase of home loan life insurance. The logistic regression analysis indicates that occupation significantly influences the purchase of home loan life insurance. This study may provide a basis for banking practitioners to develop future customers in the insurance industry.
\end{abstract}

JEL classification numbers: G21, G41, G53

Keywords: Home Loan, Home Loan Life Insurance, Insurance Industry, Logistic Regression Analysis

1 Professor, Department of Business Administration, National ChiaYi University, Taiwan.

2 Corresponding Author, Associate Professor, Department of Applied Economics, National Chia Yi University, Taiwan.

${ }^{3}$ EMBA Degree, College of Management, National Chiayi University. Taiwan.

Article Info: Received: September 24, 2020. Revised: September 29, 2020.

Published online: October 1, 2020. 


\section{Introduction}

In recent years, with the rapid rise of house prices, the pressure is increasing on both home buyers (from home loans) and Taiwanese banks (from bearing bad home loans). Therefore, Taiwanese banks will always try to sell home loan life insurance products to home loan borrowers when undertaking home loan business, with a view to transferring the risks of the banks and home loan owners to insurance companies. When home loan borrowers apply for home loans, they can get fixed-term loans coupled with life insurance policies, with the amount of insurance coverage matching the amount of the home loan. Moreover, when a borrower dies or is completely disabled due to an accident, he or she can leave with love instead of debt, and the bank can also reduce the proportion of bad debts.

Houses are the largest asset for most families. Because all houses are purchased with bank loans, home loans are the biggest debts in a lifetime. According to the statistics of the Construction and Planning Agency of the Ministry of the Interior, the average amount of each loan for a housing purchase in the fourth quarter of 2018 was about ten million New Taiwan dollars (NT\$). In the first quarter of 2018, the home loan burden rate of Taiwan citizens was $37.25 \%$, and that of Taipei city was $61.54 \%$. That means, households with home loan paid $30 \%$ to $60 \%$ of their salaries to cover the home loan, showing that the home buyers were under the pressure of huge home loans.

Additionally, according to the Life Insurance Association figures, the number of death payments made in 2018 was 195,992, and the payment amount was nearly NT\$111.4 billion, with an average national death insurance amount of about NT\$568,000. However, the Accounting and Statistics of the Executive Yuan announced that the average national income was NT\$660,000 in 2018. From the perspective of the insurance coverage, if a home loan borrower dies in an accident, the insurance compensation will not be sufficient to repay the home loan. Moreover, if a home loan borrower, as the economic pillar of the family, suffers from a sudden accident or is totally disabled due to any disease, his or her family members will not be able to repay the home loan-facing crises such as legal auction or selling the home at a low price. A husband and wife share burdens. Be it a family with a double or single salary, if there is a lack of one salary, the home loan will become a heavy burden. Therefore, if a couple buys home loan life insurance when applying for a home loan, the insurance compensation will repay the home loan and let the survivors remain in the shelter if the borrower dies or is totally disabled.

According to statistics from the Construction and Planning Agency of the Ministry of the Interior, currently about $95 \%$ of Taiwan's house purchasers apply for home loans, but only $10 \%$ buy home loan life insurance, whereas $70 \%$ to $80 \%$ in Europe and the United States buy home loan life insurance. Presently, even though the purchase of home loan life insurance by Taiwan's home loan households is obviously low, borrowers gradually increase their acceptance of home loan life insurance. This adds protection for their family amid the frequent occurrence of natural disasters, occupational injuries, and increasing cancer rates in recent years, 
causing people to feel uncertain about the repayment of home loans; with the rising price of houses, if an accident happens to a borrower with no guarantee of home loan life insurance, it is difficult for the family to repay the mortgage. Early home loan life insurance products only included death claims and disability-related payments, whereas the current home loan life insurance payments are more diversified, providing more complete protection for the insured, and include products such as major disability security and double payment for specific accidental injury and death insurance benefits from public transport, major burns and scalding, cancer, etc.

According to the statistics of the state affairs of Taiwan's Executive Yuan, as of the end of December 2018, there was a total of 38 financial institutions in Taiwan, of which 31 were in the home loan life insurance sales business. The premium income from home loan life insurance from 2016 to 2018 was, respectively, NT\$7.2 billion in 2016, NT $\$ 7.5$ billion in 2017, and NT $\$ 7.8$ billion in 2018. Among these financial institutions, the income from home loan life insurance of 11 banks in each of the past three years have each exceeded NT\$500 million. Therefore, the home loan life insurance market presents huge business opportunities, and financial and insurance companies will likely invest more manpower and resources in the future to strive for the home loan insurance market. Consequently, it is expected that this study will clarify the main factors influencing Taiwan's home loan households to purchase home loan life insurance. The research results will provide the bank practitioners with a basis for developing customers and help the insurance companies to formulate marketing strategies, select target markets, and create merchandising plans.

\section{Literature Review}

In the 1970s, the French banking industry first stepped into the life insurance business, and other countries began to use banks or other financial institutions to sell insurance products. The banking industry was one of the channels for insurance. Banks entered into the insurance business by providing various insurance products and diversified services to home loan customers. In foreign countries, the bankinsurance channel (Huizinga, 1993), or bancassurance, allows banks to provide a comprehensive financial service for individual customers by combining traditional bancassurance and investment activities (Leale-Green and Bloomfield, 1994). According to the literature, bancassurance is a new strategy for financial institutions to operate a business and serve customers.

Boyd, Graham, and Hewitt (1993) and Fields, Fraser, and Kolari (2007) pointed out that bancassurance did have the effect of diversifying risks. According to Fiordelisi and Ricci (2011), the success of bancassurance is completely connected with the effectiveness of the sales costs. When discussing the cooperation mode, Korhonen and Voutilainen (2006) mentioned that, after discussing various cooperation structures with the senior managers of Finnish banks and insurance companies in a forum, they believed that a financial holding group was the most appropriate model. 
The Swiss Reinsurance Company (2007) said that, for insurance companies, there were three big benefits for the development of bancassurance: rapidly expanding the source of customers, providing services through banks, and cooperating with banks to develop new products. By establishing financial holding companies or insurance agent companies, bancassurance consolidates marketing through marketing channels of banks, whereas the operating insurance business uses channels such as strategic alliances to improve the bank's earnings. Where the insurance and the banking industries overlap, both mutually benefit from improved competitiveness, revenue, and return on assets.

$\mathrm{Li}$ (2008) refers home loan life insurance as life insurance products matched with home loans, whereas Cho and Tseng (2013) define home loan life insurance as financial institutions (such as banks) connecting consumer home loan credit transactions with life insurance contracts. Once a debtor has an insurance accident, the insurer pays insurance compensation to the beneficiary (such as banks) to pay off the debt of his or her home loan, relieving the debtor's family members from being forced, at some point, to sell the house to repay the debt.

The home loan life insurance originated from home loans insurance. The home loans insurance system was founded first in the US in the 1880s. To date, the history of the home loans insurance system is around 140 years. Since 1876, American private home loans insurance company started to provide guarantee services on home loans, and the home loans insurance services were intended to provide protection for home loans companies. Although the provision of home loans insurance has impact on the home Loans providers' willingness and amount for lending, the insurance did not provide much benefit for the home Loans users (borrowers).The home Loans insurance was called loan-related insurance in the Europe, and creditor insurance or payment protection in the US and Canada. Based on the insured conditions, loan quality, and loan types, the loan can be categorized into personal loan insurance, lease insurance, and credit card outstanding balance insurance.

To ensure the creditor's rights, Taiwan's financial industry used to focus on guaranty insurance. However, in 1963, to implement the national housing policy, the government assisted individuals in purchasing houses within their financial resources and started the business of residential mortgage for repayment of guaranty insurance on a trial basis. In the 1990s, foreign banks and new insurance companies joined the market and assisted banks' transformations into financial holding companies, resulting in some being able to handle the home loan business. For instance, the government designated Nanshan Life Insurance to handle group term insurance to ensure banks recovered their home loan claims. This was the predecessor of "home life insurance." Later on, insurance companies gradually moved into home loan insurance purchases by individuals (Cho and Tseng, 2013). In 1993, to ensure the recovery of home loan claims, domestic banks were officially in the home loan life insurance sales business. This could not only increase the insurance fee income but also ensure the home loan claims. Consequently, banks actively sought insurance companies to jointly launch the "home loan life insurance" 
scheme. Home loan life insurance would prioritize the payment of insurance money to cover the bank's home loan debts, with the balance, if any, being paid to the beneficiary of the home loan borrower if the home loan was still outstanding, thus upholding the spirit of "leaving with love instead of debt."

Browne and Hoyt (2000) believed that the level of risk perceived by the public was related to the willingness to buy insurance. Generally speaking, those who do not have enough risk awareness pay less attention to insurance, and Brown and Finkelstein (2009) supposed that those who were worried about unexpected risks would transfer risks by buying insurance. Zhou-Richter, Browne, and Gründl (2010) mentioned that, when people perceived a higher risk of long-term care, the demand for long-term care would also increase.

Hwang and Greenford (2005) analyzed the influencing factors of life insurance consumption in mainland China, Hong Kong, and Taiwan. The results show that income and education are highly correlated with life insurance consumption, whereas the one-child policy in mainland China negatively impacts it. The more developed the national economy, the greater the life insurance consumption. Cox and Zwinkels (2019) used the survey data of the DNB Household Survey to analyze the use of Dutch homeowner's home loan life insurance. The research results show that the demand for home loan life insurance is influenced by risk exposure, type of home loan borrower, and involvement of the financial adviser. Moreover, the higher the wealth of the home loan borrowers or the lower their age group, the more likely they are to buy insurance.

Therefore, home loan life insurance is a new kind of insurance commodity in Taiwan's insurance industry. Presently, buying additional home loan life insurance is limited to the households who borrow from banks. There is a scarcity found with domestic and foreign literature discussing home loan life insurance attached to the home loan. Therefore, this study only discusses the subject home loan life insurance attached to home loans managed by Taiwanese banks based on seven influencing factors: gender, marriage, age, number of children, educational, occupation, and annual income.

\section{Research Methods}

If the category data presents discrete or binary data, it cannot satisfy the assumption that the variables should be continuous and normally distributed in the traditional regression analysis; consequently, at this time, the traditional regression analysis may not be applicable. Only when the discrete data is converted to a continuous data type between 0 and 1 can the converted continuous data be used for regression analysis. The logistic regression model can be used to analyze this type of problem. The purpose of this model is to use some continuous or categorical variables to predict the probability of an event (Y) occurring. It is mainly used when the response variable is a binary one. 
The basic pattern of logistic regression is as follows:

$$
\begin{aligned}
& \mathrm{P}_{i}=F\left(Y_{i}\right)=\frac{1}{1+\mathrm{e}^{-Y_{i}}} \\
& Y_{i}=\ln \frac{P_{i}}{1-P_{i}}=\beta^{\prime} X_{i}+\varepsilon_{i}=\beta_{0}+\beta_{1} X_{i 1}+\beta_{2} X_{i 2}+\cdots+\beta_{n} X_{i n}+\varepsilon_{i}
\end{aligned}
$$

Among them, $Y_{i}=0$ or 1 . A value of 0 means that the event does not occur, 1 means that the event occurs, $\mathrm{F}$ is the cumulative probability distribution function of logistic regression, $\beta_{0}, \beta_{1}, \beta_{2} \cdots \beta_{n}$ represents the estimated value of the parameter, $X_{i 1}, X_{i 2}, X_{i 1} \cdots X_{i n}$ represents the attribute value of the observed value, and $\varepsilon_{i}$ is an independently assigned random variable with the expected value equal to 0 .

The analytical model of this study is as follows:

$$
\begin{aligned}
& Y_{i}=\ln \frac{P_{i}}{1-P_{i}}=\beta_{0}+\beta_{1} X_{i 1}+\beta_{2} X_{i 2}+\beta_{3} X_{i 3}+\beta_{4} X_{i 4} \\
& \quad+\beta_{5} X_{i 5}+\beta_{6} X_{i 6}+\beta_{7} X_{i 7}+\varepsilon_{i}
\end{aligned}
$$

This study applies a binary classification method based on variables, using 1 for customers' additional purchase of home loan life insurance and 0 for customers' non-additional purchase of home loan life insurance; it has the aim of finding out, through the estimation of logistic regression, the main influencing factors for the additional purchase of home loan life insurance by loan customers in Taiwan. The variables include the data of the borrower's gender, marriage, age, number of children, educational, occupation, and annual income. The definition of the variables is shown in Table 1. 
Table 1: Definitions of variables

\begin{tabular}{|c|c|c|}
\hline Variable Name & Variables & Definitions \\
\hline $\mathrm{Y}$ & $\begin{array}{c}\text { Customers' } \\
\text { additional purchase } \\
\text { of home loan life } \\
\text { insurance }\end{array}$ & $\begin{array}{l}\text { Using } 0 \text { for customers' non-additional } \\
\text { purchase of home loan life insurance. } \\
\text { Using } 1 \text { for customers' additional purchase } \\
\text { of home loan life insurance }\end{array}$ \\
\hline $\mathrm{X} 1$ & Gender & 1. Male '2. Female \\
\hline $\mathrm{X} 2$ & Marriage & 1.Unmarried 2. Married \\
\hline $\mathrm{X} 3$ & Age & 1. Less than $30 \cdot 2.31-40 \cdot 3$. Above 41 \\
\hline $\mathrm{X} 4$ & Number of Children & Actual Number of Children \\
\hline $\mathrm{X} 5$ & Education & $\begin{array}{l}\text { 1. High School diploma or less } \\
\text { 2. University/ college } \\
\text { 3. Post University }\end{array}$ \\
\hline $\mathrm{X} 6$ & Occupation & $\begin{array}{l}\text { 1. Manufacturing } \\
\text { 2. Service Industry } \\
\text { 3. Others }\end{array}$ \\
\hline $\mathrm{X} 7$ & $\begin{array}{l}\text { Annual Income } \\
\text { (NT Dollar) }\end{array}$ & $\begin{array}{l}\text { 1. Less than } 500,000 \\
\text { 2. } 500,001-1,000,000 \\
\text { 3. Above } 1,000,001\end{array}$ \\
\hline
\end{tabular}

\section{Data Analysis}

\subsection{Sample descriptive statistics}

This study analyzes the customers who applied with Taiwanese banks for home loans between 2014-2018. Among a total of 417 cases, 62 customers purchased additional home loan life insurance while 355 did not. Table 2 indicates the following: the majority were male, accounting for $63.5 \%$; married persons accounted for $56.1 \%$; the highest age group proportion was $31-40$ years old, accounting for $49.6 \%$; for the number of children category, those without children accounted for $53.9 \%$; for education level, $56.6 \%$ were university or college students; $59.5 \%$ were manufacturing workers; and for annual income, the largest group comprised individuals earning NT\$500,001-NT\$1,000,000, accounting for $44.8 \%$. 
Table 2: Frequency distribution of sample characteristics

\begin{tabular}{|c|c|c|c|}
\hline Variables & Items & Frequency & $\%$ \\
\hline \multirow[t]{2}{*}{ Gender } & Male & 265 & 63.5 \\
\hline & Female & 152 & 36.5 \\
\hline \multirow[t]{2}{*}{ Marriage } & Unmarried & 183 & 43.9 \\
\hline & Married & 234 & 56.1 \\
\hline \multirow[t]{3}{*}{ Age } & Less than 30 & 79 & 19.0 \\
\hline & $31-40$ & 207 & 49.6 \\
\hline & Above 41 & 131 & 31.4 \\
\hline \multirow{4}{*}{$\begin{array}{l}\text { Number of } \\
\text { Children }\end{array}$} & 0 & 225 & 53.9 \\
\hline & 1 & 72 & 17.3 \\
\hline & 2 & 100 & 24.0 \\
\hline & Above 3 & 20 & 4.8 \\
\hline \multirow[t]{3}{*}{ Education } & $\begin{array}{c}\text { High School diploma or } \\
\text { less }\end{array}$ & 96 & 23.0 \\
\hline & University/ college & 236 & 56.6 \\
\hline & Post University & 85 & 20.4 \\
\hline \multirow[t]{3}{*}{ Occupation } & Manufacturing & 248 & 59.5 \\
\hline & Service Industry & 90 & 21.6 \\
\hline & Others & 79 & 18.9 \\
\hline \multirow{3}{*}{$\begin{array}{c}\text { Annual } \\
\text { Income } \\
\text { (NT Dollar) }\end{array}$} & Less than 500,000 & 103 & 24.7 \\
\hline & $500,001 \sim 1,000,000$ & 187 & 44.8 \\
\hline & Above $1,000,001$ & 127 & 30.5 \\
\hline
\end{tabular}

\subsection{Lender characteristics and verification of additional purchase of home life insurance}

The purpose of this study is to understand the relationship between various variables of borrowers and their willingness to purchase additional home loan life insurance and, further, to cross-analyze and chi-squire test the variables of gender, marriage, age, number of children, education, occupation, and annual income of the borrowers as well as the willingness to purchase additional home loan life insuranceproviding a reference for Taiwanese banks in their search for potential customers when promoting the home loan life insurance business.

From the cross-analysis of the variables and the willingness to purchase additional home loan life insurance in Table 3, it is found that the proportion of men willing to purchase additional home loan life insurance is $51.6 \%$, which is higher than women $(48.4 \%)$. Because men are usually the main economic source of the family, their death, sickness, or injury will cause great economic pressure on the family, so the demand for additional home loan life insurance is relatively high. In terms of marriage, the proportion of people willing to purchase additional home loan life insurance is the same, irrespective of their marital status. 
The group aged 31-40 registers both the highest proportion (49\%) in home loan arrangements and the highest proportion (53.2\%) in additional purchases of home loan life insurance. The cross-analysis of the number of children and the additional purchase of home loan life insurance shows that the highest proportion $(61.3 \%)$ of the people who additionally purchase home loan life insurance are those without children; the second place (21\%) are those with one child. Because of the policy of the Taiwanese government in recent years, people who arrange home loans with banks are mostly young, newlywed, and first-time buyers, so the proportion of people with children is relatively low. It also shows that consumers are aware of the risks when passing it onto the insurance companies, thus increasing the additional purchase of home loan life insurance.

The cross-analysis of educational and the additional purchase of home loan life insurance finds that the highest group (64.5\%) of the people who bought additional home loan life insurance are university and college graduates. This could result, thanks to a higher education level, from a better understanding of the uncertainty of life and the financial security needed by the dependents, thus bringing an increased demand for life insurance. The cross-analysis of occupation and the additional purchase of home loan life insurance shows that, at $45.2 \%$, people from the manufacturing sector bought the most home loan life insurance, followed by those in the service industry $(37.1 \%)$. This is mainly because the manufacturing and service industries are Taiwan's main industries and, consequently, most of the loan applications are from those in these industries. As for the cross-analysis of annual income and the additional purchase of home loan life insurance, the first group (accounting for 50.0\%) is with people who earn NT\$500,001-NT\$1,000,000 per year. Generally speaking, disposable income increases when salary income increases because insurance premiums become more affordable and the willingness to insure will increase as well.

According to the results of the chi-square test, only two variables-gender and occupation-were found to significantly impact the willingness of home loan borrowers with Taiwanese banks to purchase additional home loan life insurance, whereas marriage, age, number of children, educational, and annual income had no significant impact. 
Table 3: Cross-analysis and Chi-square test

\begin{tabular}{|c|c|c|c|c|c|c|c|}
\hline \multirow[t]{2}{*}{ Variables } & \multirow[t]{2}{*}{ Items } & \multicolumn{2}{|c|}{$\begin{array}{l}\text { Customers' non-additional } \\
\text { purchase of home loan life } \\
\text { insurance }\end{array}$} & \multicolumn{2}{|c|}{$\begin{array}{l}\text { Customers' additional purchase } \\
\text { of home loan life insurance }\end{array}$} & \multirow[t]{2}{*}{$X^{2}$} & \multirow[t]{2}{*}{$p$ (sig.) } \\
\hline & & Total Frequency & $\%$ & Total Frequency & $\%$ & & \\
\hline \multirow[t]{2}{*}{ Gender } & Male & 233 & 65.6 & 32 & 51.6 & \multirow[t]{2}{*}{$4.479 * *$} & \multirow[t]{2}{*}{0.034} \\
\hline & Female & 122 & 34.4 & 30 & 48.4 & & \\
\hline \multirow[t]{2}{*}{ Marriage } & Unmarried & 152 & 42.8 & 31 & 50.0 & \multirow[t]{2}{*}{1.106} & \multirow[t]{2}{*}{0.293} \\
\hline & Married & 203 & 57.2 & 31 & 50.0 & & \\
\hline \multirow[t]{3}{*}{ Age } & Less than 30 & 64 & 18.0 & 15 & 24.2 & \multirow[t]{3}{*}{3.057} & \multirow[t]{3}{*}{0.217} \\
\hline & $31-40$ & 174 & 49.0 & 33 & 53.2 & & \\
\hline & Above 41 & 117 & 33.0 & 14 & 22.6 & & \\
\hline \multirow{4}{*}{$\begin{array}{l}\text { Number of } \\
\text { Children }\end{array}$} & 0 & 187 & 52.7 & 38 & 61.3 & \multirow[t]{4}{*}{4.399} & \multirow[t]{4}{*}{0.221} \\
\hline & 1 & 59 & 16.6 & 13 & 21.0 & & \\
\hline & 2 & 91 & 25.6 & 9 & 14.5 & & \\
\hline & Above 3 & 18 & 5.1 & 2 & 3.2 & & \\
\hline \multirow[t]{2}{*}{ Education } & High School diploma or less & 82 & 23.1 & 14 & 22.6 & \multirow[t]{2}{*}{2.813} & \multirow[t]{2}{*}{0.245} \\
\hline & $\begin{array}{l}\text { University/ College } \\
\text { Post University }\end{array}$ & $\begin{array}{c}196 \\
77\end{array}$ & $\begin{array}{l}55.2 \\
21.7\end{array}$ & $\begin{array}{c}40 \\
8\end{array}$ & $\begin{array}{l}64.5 \\
12.9\end{array}$ & & \\
\hline \multirow[t]{3}{*}{ Occupation } & Manufacturing & 220 & 62.0 & 28 & 45.2 & \multirow[t]{3}{*}{$10.685 * * *$} & \multirow[t]{3}{*}{0.005} \\
\hline & Service Industry & 67 & 18.9 & 23 & 37.1 & & \\
\hline & Others & 68 & 19.1 & 11 & 17.7 & & \\
\hline \multirow{3}{*}{$\begin{array}{c}\text { Annual } \\
\text { Income } \\
\text { (NT Dollar) }\end{array}$} & Less than 500,000 & 86 & 24.1 & 17 & 27.4 & \multirow[t]{3}{*}{2.133} & \multirow[t]{3}{*}{0.344} \\
\hline & $500,001 \sim 1,000,000$ & 156 & 43.9 & 31 & 50.0 & & \\
\hline & Above $1,000,001$ & 113 & 31.8 & 14 & 22.6 & & \\
\hline \multicolumn{2}{|c|}{ Number of Respondents } & 355 & 100 & 62 & 100 & & \\
\hline
\end{tabular}

Note : ***,** and $*$ denote the $0.01 \cdot 0.05 \cdot 0.1$ significant level respectively. 


\subsection{Logistic Regression Analysis}

To further determine the factors that affect the customers' willingness to buy additional home loan life insurance, a logistic regression was used to analyze the seven variables (i.e., gender, marriage, age, number of children, educational, occupation, and annual income) and the willingness to buy additional home loan life insurance. Firstly, we tested the suitability of information under the logistic regression model. The test results show that, for the suitability of the overall model, the chi-square test statistics reach a significant level of $24.976(\mathrm{P}<0.05)$, which means that, out of the seven variables, at least there was one independent variable that could effectively explain the results of the dependent variables, representing that the overall model has significant explanatory power, as shown in Table 4. According to the results of the logistic regression analysis, the only factor that impacts the willingness to purchase additional home loan life insurance is the service industry in the occupational category. Because the odds ratio of the service industry coefficient is less than 1 , it means that the customers in the service industry have a significant, negative relationship with their willingness to purchase additional home loan life insurance. Specifically, the customers in the service industry have a lower willingness to purchase additional home loan life insurance than other customers. However, the odds ratio of the manufacturing industry coefficient is greater than 1 , showing that there is a positive relationship between customers in the manufacturing industry and the willingness to buy additional home loan life insurance. Namely, customers in the manufacturing industry are more willing to buy additional home loan life insurance than other customers. Therefore, different occupational categories have different effects on whether they want to buy additional home loan insurance. It also seems that different occupations surely bring different impacts, having explored the differences in social and economic conditions and thoughts on insurance. The other six variables (i.e., gender, marriage, age, number of children, education, and annual income), present no significant influence; however, the odds ratio perspective indicates that men are still willing to buy additional home loan life insurance compared with women. Furthermore, people of a relatively young age are less willing to buy it compared with older ones; the willingness of those with a university or a college education is also lower than those with research institutes, as shown in Table 4. 
Table 4: Logistic regression analysis

\begin{tabular}{|c|c|c|c|c|c|}
\hline Variables & $\beta$ (coefficient) & S.E & $p$ (sig.) & $\begin{array}{c}\operatorname{Exp}(B) \\
\text { (odds radio) }\end{array}$ & $\begin{array}{c}95 \% \text { CI } \\
\text { (odds radio) }\end{array}$ \\
\hline \multicolumn{6}{|l|}{ Gender } \\
\hline Male & 0.466 & 0.305 & 0.127 & 1.593 & $0.877-2.897$ \\
\hline \multicolumn{6}{|l|}{ Marriage } \\
\hline Unmarried & 0.002 & 0.351 & 0.996 & 1.002 & $0.504-1.992$ \\
\hline \multicolumn{6}{|l|}{ Married(relative) } \\
\hline $31-40$ & -0.482 & 0.383 & 0.209 & 0.618 & $0.291-1.310$ \\
\hline \multicolumn{6}{|l|}{ Above 41(relative) } \\
\hline \multicolumn{6}{|l|}{ Number of Children } \\
\hline 0 & -0.586 & 0.839 & 0.485 & 0.557 & $0.107-2.885$ \\
\hline 1 & -0.863 & 0.850 & 0.310 & 0.422 & $0.080-2.234$ \\
\hline 2 & -0.088 & 0.860 & 0.918 & 0.916 & $0.170-4.935$ \\
\hline \multicolumn{6}{|l|}{ Post University(relative) } \\
\hline \multicolumn{6}{|l|}{ Occupation } \\
\hline Manufacturing & 0.200 & 0.396 & 0.613 & 1.222 & $0.563-2.653$ \\
\hline Service Industry & $-0.790 * *$ & 0.418 & 0.049 & 0.454 & $0.200-1.030$ \\
\hline \multicolumn{6}{|l|}{ Others(relative) } \\
\hline \multicolumn{6}{|l|}{ Annual Income (NT Dollar) } \\
\hline Less than 500,000 & 0.061 & 0.453 & 0.892 & 1.063 & $0.438-2.583$ \\
\hline $500,001 \sim 1,000,000$ & -0.089 & 0.392 & 0.820 & 0.915 & $0.424-1.972$ \\
\hline Above $1,000,001$ (relative) & & & & & \\
\hline$X^{2}=24,976$ & $=0.031$ & & & & \\
\hline
\end{tabular}

Note : ***,** and $*$ denote the $0.01 \cdot 0.05 \cdot 0.1$ significant level respectively. 


\section{Conclusions and Suggestions}

\subsection{Conclusions}

The research objects of this study are customers who applied for a home loan with Taiwanese banks between 2014-2018. Of the total of 417 customers, 62 additionally purchased home loan life insurance, and 355 did not. Seven variablesgender, marriage, age, number of children, educational, occupation, and annual income - are separately tested against the willingness to purchase additional home loan life insurance. The chi-square test has found that only two variables, gender and occupation, significantly impact the additional purchase of home loan life insurance. Gender is a variable with significant impacts and indicates that most of the applicants for home loans and home loan life insurance are men. Men are usually the main source of income for families. If they die, get sick, or become disabled, the families will suffer from great economic pressure. Therefore, to ensure that families have a safe life in the future, life insurance is in relatively high demand. Furthermore, the other factor that has brought a difference among occupations is that many were with the manufacturing industry, which presents a relatively high risk coefficient and a relatively high degree of acceptance of insurance.

The results of the logistic regression analysis show that among the seven variables (gender, marriage, age, number of children, educational, occupation, and annual income), only occupation has a significant impact: a significant, negative impact on customers in the service industry and their willingness to buy additional home loan life insurance. That is, customers in the service industry have a lower willingness to buy additional home loan life insurance than other customers, whereas the manufacturing sector positively impacts customers from that industry in terms of their intent to buy home loan life insurance - meaning that these customers are more willing to purchase additional home loan life insurance than other customers. This study aims to provide a basis for banking practitioners in their development of future customers and offering references for insurance companies to choose marketing strategies, target markets, and merchandising plans, thus helping sales of home loan life insurance.

\subsection{Suggestions}

Banks can make good use of emotional marketing tactics with men engaged in manufacturing and potential customers aged 31-40, emphasizing the advantages of home loan life insurance products that can provide protection and risk transfer, improving potential customers' purchase willingness. Banks can also provide commodity information to builders and advocate that additional home loan life insurance can prevent a house from being auctioned or sold at a cheap price when the homeowner dies unexpectedly. Furthermore, the information passed on by the builders' sales staffs will help home loan borrowers gain a preliminary understanding of the home loan life insurance. Finally, at the time of a home loan application, bank personnel may explain the underwriting conditions and contents to the home loan borrowers, where the insurance intent could be enhanced. 
Given the younger the age, the less the premium banks can offer fixed-rate life insurance to young home loan borrowers, whereas the elderly can buy decreasing or regular payment-type insurance products. With a small insurance fee every month, the risk can be transferred to the insurance company and the spirit of "leave with love instead of debt" can be passed on to the home loan borrowers in the event of accidental death. Accordingly, the willingness to buy home loan life insurance will be improved. People in the insurance business may, through a strategic alliance with large banks, expand marketing channels and actively develop life insurance products suitable for home loan customers - creating a win-win model by combining the sales with the home loan business. Moreover, the banks should establish a special department for home loan life insurance and provide training on sales skills and professional knowledge to lending staff to meet the demand for the after-sales service of home loan customers. 


\section{References}

[1] Boyd, J, H., S. L. Graham and R. S. Hewitt, Bank holding company mergers with nonbank financial firms: effects on the risk of failure. Journal of Banking and Finance, 1993, 17:1, 43-64.

[2] Brown, J. R. and A. Finkelstein, The private market for long-term care insurance in the United States: a review of the evidence. Journal of Risk and Insurance, 2009, 76:1, 5-29.

[3] Browne, M. J. and R. E. Hoyt, The demand for flood insurance: empirical evidence. Journal of Risk and Uncertainty, 2000, 20:3, 291-306.

[4] Cho, C. H. \& Tseng, Y. F. (2013). The research of practical operations and legal issues of mortgage life insurance. Tunghai University Law Review, 40, 129-182.

[5] Fields, L. P., D. R. Fraser and J. W. Kolari, Is bancassurance a viable model for financial firms? Journal fo risk and Insurance, 2007, 74, 777-794.

[6] Fiordelisi, F. and O. Ricci, Bancassurance efficiency gains: evidence from the Italian banking and insurance industries. The European Journal of Finance, 2011, 17, 789-810.

[7] Huizinga, H. Banking and insurance: an ideal combination? The insurance Perspective, London, 1993.

[8] Hwang, T. and B. Greenford, A cross-section analysis of the determinants of life insurance consumption in Mainland China, Hong Kong, and Taiwan, Risk Management and Insurance Review, 2005, 8, 103-125.

[9] Korhonen, P. and R. Voutilainen, Finding the most preferred alliance structure between banks and insurance companies. European Journal of Operational Research, 2006, 175, 1285-1299.

[10] Leale-Green, H. and J. Bloomfield, Bancassurance: the shape of things to come. Post Magazin, 1994, 23, 16-19.

[11] Li-Jung Li. New financial products: the risk of fastening mortgage loan on ILife insurance. Consumer Reports of Taiwan, 2008, 333, 54-58.

[12] Cox, R. H. G. M. and R. C. J. Zwinkels, Mortgage insurance adoption in the Netherlands. Real Estate Economic, 2019, 47:4, 977-1012.

[13] Swiss Reinsurance Company, Bancassurance: Emerging Trends, Opportunities and Challenges, Sigma, 2007, 5, 1-39.

[14] Zhou-Richter, T., M. Browne and H. Gründl, Don't they care? or, are they just unaware? Risk perception and the demand for long-term care insurance. Journal of Risk and Insurance, 2010, 77:4, 715-747. 